\title{
BASIC SANITATION IN SMALL COMMUNITIES
}

\author{
Anna V. M. Machado ${ }^{1}$ \\ Dario de A. Prata Filho ${ }^{2}$ \\ Ricardo Franklin P. Britto ${ }^{3}$ \\ Aline M. Naue ${ }^{4}$ \\ Carolina B. M. L. Costa
}

\begin{abstract}
Improving the coverage of water supply and sanitation has positive impacts on economic, social and health conditions. In Brazil, the deficit in water supply and sanitation in urban areas has been reduced due to recent government investments, but are still insufficient for the service universalization. Deficiencies in water supply and sanitation are observerd in rural areas of Brazil because, historically, these areas have not received sufficient investment. This paper presents the alternatives adopted in rural communities in Brazil, with at least 2500 inhabitants, being those successful experiences that can be replicated. Research stages involved literature surveys, interviews with experts and with community representatives, and field trips. The interviews and field trips allowed the knowledge of local realities, of appropriate technical solutions, the uptake and levels of community awareness, the operational problems and the management systems frequently applied.
\end{abstract}

Keywords: rural sanitation, simplified technology.

\section{INTRODUCTION}

Brazil has subscribed the Millennium Development Declaration, which stipulates that by 2015 the proportion of people without access to water supply and sanitation will be reduced by half.

Moreover, Brazil has committed (Law $\mathrm{n}^{\circ}$ 11.445, 5 Jan 2007) to achieve, by 2030, basic sanitation services universal coverage (in water supply, sewerage, solid waste management and drainage). According to statistics presented in the National Monitoring Report (IPEA, 2010), about two thirds of Brazilians who live outside urban areas are not supplied with basic sanitation services, thus vulnerable to various diseases and consequently in a social risk.

Since the majority of the investment has been made to serve urban areas, the basic motivation of this work has focused on producing a paper that could present the successful experi- ences applied in small and rural communities. It describes the technical solutions and management service formats more frequently in use. Therefore, the aim is to provide further information on the subject, revealing the feasibility of implementing technologies to be replicated in different situations, thus hoping to contribute to the evolution in rural sanitation in Brazil.

\section{MATERIALS AND METHODS}

The study was conducted at the Laboratory of Environmental Management, TDT/ at the School of Engineering, Universidade Federal Fluminense, in the period April to August 2010.

A literature review and interviews with professionals, institutions and representative members of the rural communities were conducted as well as field visits (Figure 1).

1 Civil Eng., $M S c$; Professor of School of Engineering at Federal Fl Pátria St., 156, Postal Code 24210-240 - Niterói, RJ.

2 Civil and Sanitary Eng, Agricultural Eng., MSc Professor of School of Engineering at Federal Fluminense University; darioprata@gmail.com.

3 Under Graduated Student of Environmental and Agricultural Eng. on School of Engineering at Federal Fluminense University, rfpbritt@ vm.uff.br

${ }^{4}$ Under Graduated Student of Architecture and Urban Planning on School of Architecture and Urban Planning at Federal Fluminense University, alinemanera@hotmail.com

5 Under Graduated Student of Environmental and Agricultural Eng. on School of Engineering at Federal Fluminense University, carolina. lobato@gmail.com 


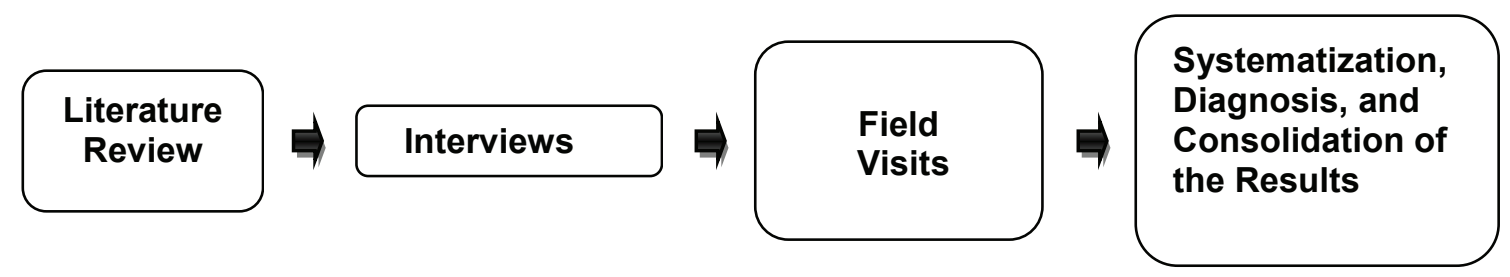

Figure 1 - Methodological approach

The literature review considered the conference proceedings, especially the conventions of sanitary and environmental engineering, Brazilian and international, seminars of public health engineering, national seminars on rural sanitation, and other events. In the 52 articles surveyed, we sought to identify experiences applied in Rural Sanitation in Brazil, listing the technologies used, as well as the management systems deployed, their advantages and disadvantages.

The interviews took place in June 2010, by occasion of the Models and Management Systems of Rural Sanitation Seminar held at Pan American Health Organization in Brasilia. Interviews were held with professionals from the states of Minas Gerais, São Paulo, Ceará, Espirito Santo, Paraná, Piaui and Pernambuco, all working in the area of Rural Sanitation, in order to get information about the current technologies and systems used, their management systems, the operational problems and solutions more frequently observed.

The field visits were conducted in $10 \mathrm{mu}$ nicipalities and 11 communities in the states of Ceará and Pernambuco (Quadro 1).

Table 1 - Municipalities and Communities visited

\begin{tabular}{|c|c|c|}
\hline States & Municipalities & Communities \\
\hline Ceará & $\begin{array}{c}\text { Ocara, Quixadá, Itapipoca, Aracati, } \\
\text { Fortim, Russas. }\end{array}$ & $\begin{array}{c}\text { Córrego da Catita, Sítio Retiro, Guagirú, Córrego } \\
\text { dos Rodrigues, Complexo do Batente, California, } \\
\text { Complexo da Baleia. }\end{array}$ \\
\hline Pernambuco & $\begin{array}{c}\text { Alliança, Ferreiros, Itaquitinga, Rio } \\
\text { Formoso }\end{array}$ & $\begin{array}{c}\text { Santa Luzia, Encruzilhada, Chã de Sapé and } \\
\text { Conceição }\end{array}$ \\
\hline
\end{tabular}

The selection of locations to be visited was determined by the successful experience of SISAR (applied in Ceará state) and of PROMATA (applied in Pernambuco state). Both programs contemplated simplified and adapted technologies and management systems, applied regionally.

For evaluation purposes, a compilation and discussion were done on the obtained data.

\section{RESULTS AND DISCUSSION}

Concerning the management alternatives to organize water supply systems the community participation became evident.

The systems identified were mostly built with funding from state or federal governments, often with the participation of financial agents.
Currently, they are operated mostly by associations of users organized in local level.

The case of the management model SISAR was identified in Ceará. This model joins in a regional institution, associations of local users who operate the services in the communities, providing technical, administrative and social support assistance. The water and sanitation state company CAGECE provide technical support and dedicate a 4 members staff for assistance to the SISAR's. There are 8 SISAR's in Ceará, organized in regional institutions. The SISAR-CE systems are located in the northeast region in Brazil.

It is necessary to identify a water source that allows a low-cost treatment. The flow of water supply should meet the demand from a population at a growth of $2 \%$ per year with a 
project horizon of 20 years. The physical and chemical parameters must be in accordance with "Portaria" no 518 of March 25, 2004 from the Ministry of Health. Having these conditions being satisfied a water supply system is built and an association of local users is established to join SISAR.

Concerning the technological alternative to provide water supply for small communities, a local solution is considered.

In the majority of municipalities visited, the water is supplied from deep wells and treatment is a simple chlorination. The elevated tank is used to distribute the water using gravity (Figure 2). There is a meter at the end of the treatment and others at each water connection. The cost to be payed for each connection is calculated considering the water used plus the operation cost.

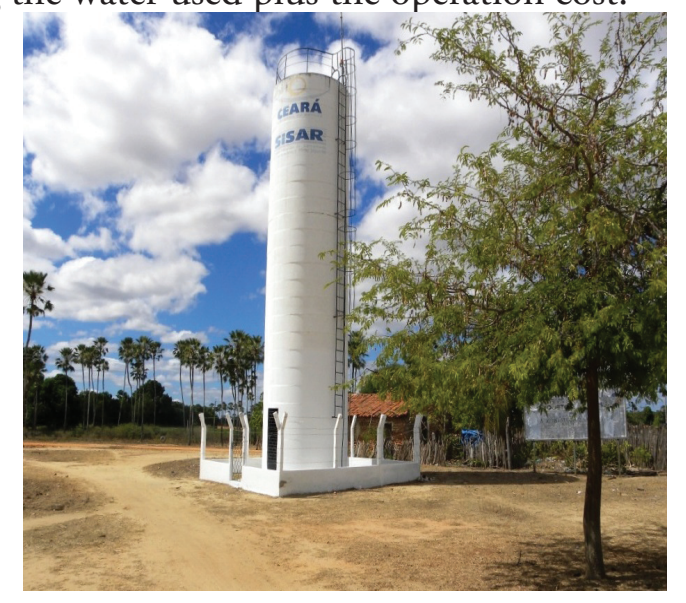

Figure 2 - Elevated Tank-Community of Córrego da Catita-Municípío Russas-CE

The same water supply system, with deep wells, simple chlorination with elevated tank for distribution was also found in several municipalities of the state of Pernambuco.

In cases where the incidence of iron in the water is beyond the standards of drinking water, a tower aerator has been used to remove iron. This is the case identified in the community of Guagiru, in the municipality of Fortim, state of Ceara.
In deep wells where the water collected has high salinity, a desalinator is used as it was observed in the community of Encruzilhada in the municipality of Ferreiros, Pernambuco (Figure 3). This alternative is applied in several localities. Difficulties in operation and maintenance of the system are verified in some cases, as the replacement of parts, and the specialized technical assistance, that is not always available.

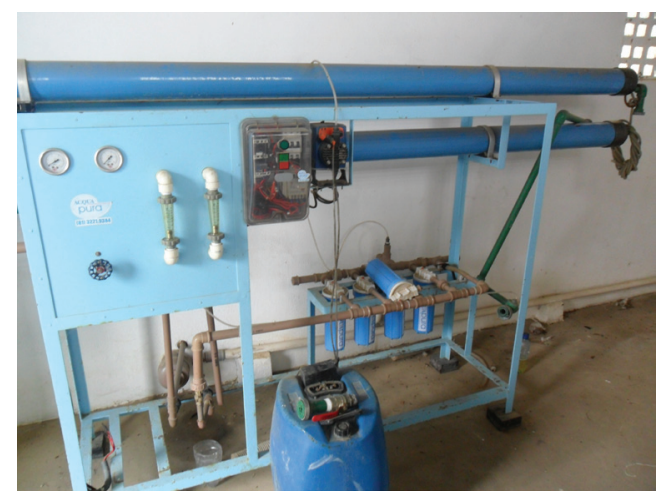

Figure 3 - Desalinator, Community of Encruzilhada Ferreiras- PE

Coordinated by the Brazilian Ministry of Social Development, the "Programa Cisternas" supports the construction of many systems in order to ensure access to drinking water for human consumption. The use of cisterns to capture rain water is found mostly in semi-arid areas, allowing the water supply in dry seasons.

The cistern is a technology for capturing rainwater and it represents a solution to access water for rural population in semi-arid areas (Figure 4). It is used by low-income rural population that suffers from the effects of prolonged droughts, which can last eight months of the year. During this period, the usual access to water has very low quality, and causes diseases. The absence, shortage, irregularity and poor distribution of rainfall during the rainy season, the intense evaporation during the dry season are key factors to characterize a severe water shortage in cisterns.
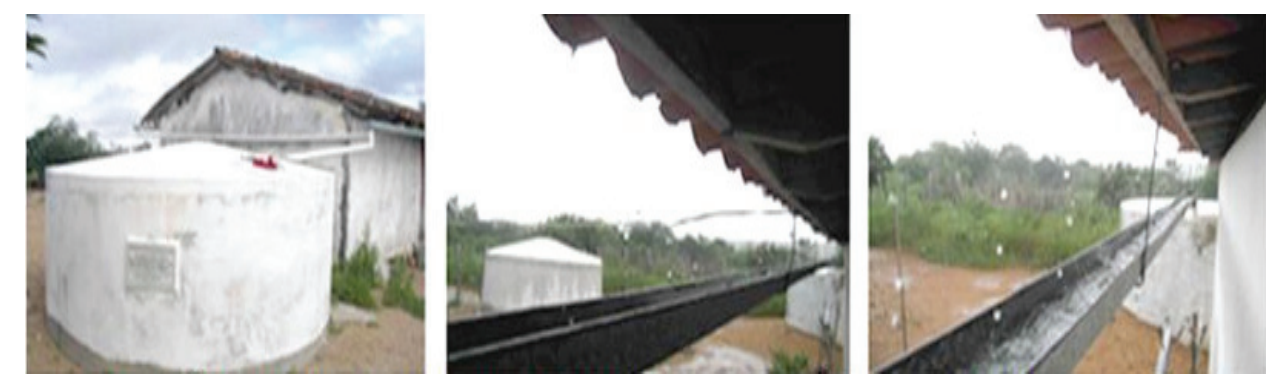

Figure 4 - Cistern and the capture of rainwater

Source: Ministry of Social Development. Cisterns 
In some municipalities the capture of water in dams has been observed, with the installation of a water treatment plant that allows the supply of various communities.
In the city of Ocara in Ceará, the water is captured in the dam "Batente", receiving treatment on a water treatment plant composed of three upflow filters, two aerators and two gravity chlorinator tablets (Figure 5).

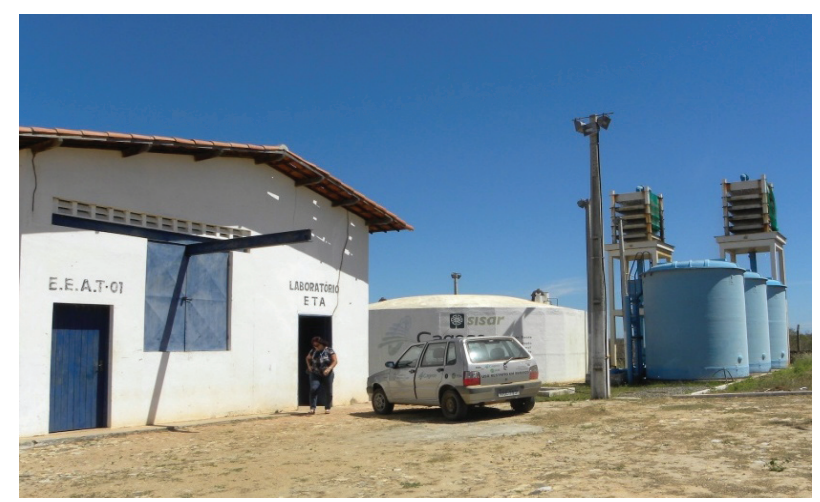

Figure 5 - "Batente" Complex, Ocara-PE

Concerning the alternative for sanitation and disposal of domestic waste water, only local solutions were applied.
The sewage systems in rural areas are generally individualized, using septic tanks and sinks (Figure 6), but there are still many rural communities without any kind of treatment for sewage.
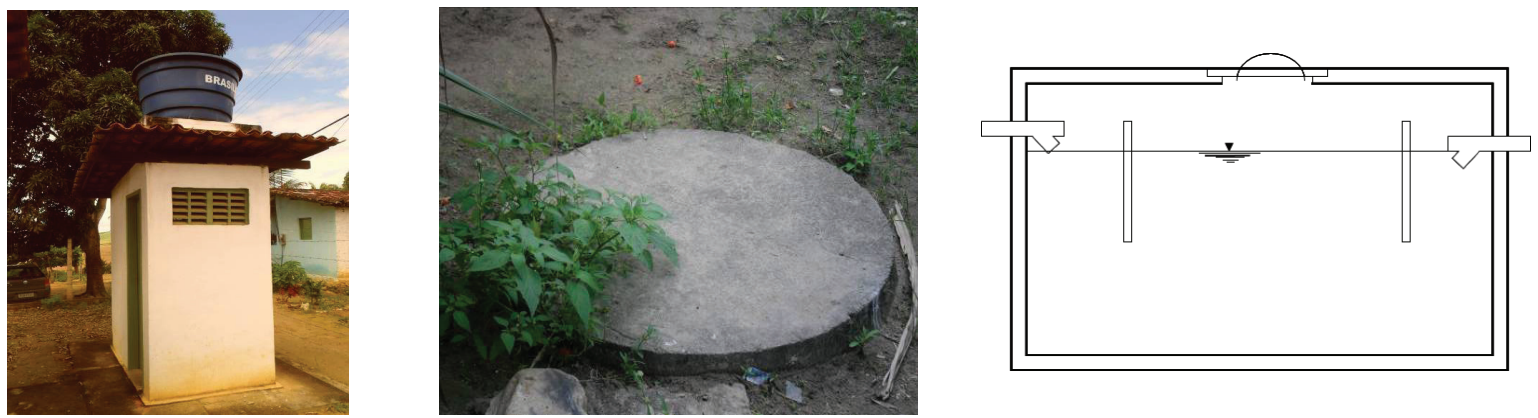

Figure 6 - Toilet with use of Septic Tank

The Model (SISAR) implanted in Piauí, with support from the German bank KFW, uses the expertise developed in Ceará, and already incorporates into their planning the need to provide communities with adequate sanitation systems.

In many communities, attention has not been given to sanitation, indicating that this was not a priority. The prospect of expanding the service has recently been taken in consideration, adopting a single solution for the sewage, and the implementation of collective systems is on its way - specially the condominial alternative. By the nature of their small scale, most systems do not involve the direct participation of a water supply and sanitation estate company which can impair the efficiency of its operation and maintenance, due to difficulties in their operation and maintenance.

\section{CONCLUSIONS}

Reducing the number of people without water supply and sanitation in rural and small communities is a challenge that requires an specific approach for technological as well management alternatives. The investment for construction of new systems must be accompanied by educational and capacity building actions and by the strengthening of community organization and participation.

The management system is as important as the technological alternative on this matter. The availability of water meters for micro and macro measurement is important to identify problems, to charge the consumption and to provide information needed for governance. The associations of users organized in local level are an important tool 
to provide management for water supply systems in small communities. The projects must consider the community participation on the management of the systems when the technological alternatives are been decided.

The extraction of water from deep wells with simple chlorination connected to a distribution network is the most used alternative for water supply in rural areas, especially in the northeast of Brazil. In the cases where salinity is high, a desalinator equipment is required. The domiciliary use of cisterns for storage of rainwater has also been verified, which enables storing water collected in rainy periods, especially in semi-arid regions of Brazil.

The septic tank is often used as a treatment alternative, however only in a few cases the maintenance and proper disposal of the sludge is considered.

\section{REFERENCES}

BRASIL. Law No 11.445, 5 JAN 2007. Available at: http://www.planalto.gov.br/ccivil_03/_ ato2007-2010/2007/lei/111445.htm>. Acess: 5 mai 2010 .
$\mathrm{RDH}$, Relatório de Desenvolvimento Humano de 2006. PNUD, United Nations Development Programme, Site oficial: (www.pnud.org.br acedido em novembro de 2006).

FSESP, Manual de Saneamento. (1999/2000). FUNASA, Rio de Janeiro. Available at: (http:// www.funasa.gov.br/pub/manusane/manusan00. htm acess: Nov 2007).

BRASIL. Ipea. Objetivos de Desenvolvimento do Milênio - Relatório Nacional de Acompanhamento. 2010. ed. Brasilia- DF, 2010. 184 p. Available at: <http://www.ipea.gov.br/portal/images/stories/PDFs/100408_relatorioodm.pdf>. Acess: 14 ago. 2010.

UNITED NATIONS. 55/2. United Nations Millennium Declaration. resolution adopted by the General Assembly. 55/2. Sept 18, 2000. Available at: <http://www.un.org/millennium/declaration/ares552e.htm>. Acess: 28 mar. 2011. 